\title{
EXPOSURE OF NONBREEDING MIGRATORY SHOREBIRDS TO CHOLINESTERASE- INHIBITING CONTAMINANTS IN THE WESTERN HEMISPHERE
}

\author{
Khara M. Strum ${ }^{1,6}$, Michael J. Hooper ${ }^{2,7}$, Kevin A. Johnson ${ }^{3}$, Richard B. Lanctot ${ }^{4}$, \\ María Elena Zaccagnini ${ }^{5}$, And Brett K. SAndercock ${ }^{1}$ \\ ${ }^{1}$ Division of Biology, Kansas State University, 116 Ackert Hall, Manhattan, KS 66506 \\ ${ }^{2}$ The Institute of Environmental and Human Health, Texas Tech University, 1207 Gilbert Avenue, Lubbock, TX 79416 \\ ${ }^{3}$ Department of Chemistry and Environmental Sciences, Southern Illinois University Edwardsville, Edwardsville, IL 62026 \\ ${ }^{4}$ U.S. Fish and Wildlife Service, Migratory Bird Management, 1011 East Tudor Road, Anchorage, AK 99503 \\ ${ }^{5}$ Instituto de Recursos Biológicos, INTA-CIRN, Los Reseros y Las Cabañas, s/n, 1712, Castelar, Buenos Aires, Argentina
}

Abstract. Migratory shorebirds frequently forage and roost in agricultural habitats, where they may be exposed to cholinesterase-inhibiting pesticides. Exposure to organophosphorus and carbamate compounds, common anti-cholinesterases, can cause sublethal effects, even death. To evaluate exposure of migratory shorebirds to organophosphorus and carbamates, we sampled birds stopping over during migration in North America and wintering in South America. We compared plasma cholinesterase activities and body masses of individuals captured at sites with no known sources of organophosphorus or carbamates to those captured in agricultural areas where agrochemicals were recommended for control of crop pests. In South America, plasma acetylcholinesterase and butyrylcholinesterase activity in Buff-breasted Sandpipers was lower at agricultural sites than at reference sites, indicating exposure to organophosphorus and carbamates. Results of plasma cholinesterase reactivation assays and foot-wash analyses were inconclusive. A meta-analysis of six species revealed no widespread effect of agricultural chemicals on cholinesterase activity. However, four of six species were negative for acetylcholinesterase and one of six for butyrylcholinesterase, indicating negative effects of pesticides on cholinesterase activity in a subset of shorebirds. Exposure to cholinesterase inhibitors can decrease body mass, but comparisons between treatments and hemispheres suggest that agrochemicals did not affect migratory shorebirds' body mass. Our study, one of the first to estimate of shorebirds' exposure to cholinesterase-inhibiting pesticides, suggests that shorebirds are being exposed to cholinesterase-inhibiting pesticides at specific sites in the winter range but not at migratory stopover sites. Future research should examine potential behavioral effects of exposure and identify other potential sites and levels of exposure.

Key words: Buff-breasted Sandpiper, carbamate, nonbreeding, organophosphate, population declines, sandpiper, Tryngites subruficollis, waders.

Exposición de Aves Playeras Migratorias No Reproductivas a Contaminantes Inhibidores de la Colinesterasa en el Hemisferio Oeste

Resumen. Las aves playeras migratorias pueden atravesar grandes distancias durante sus movimientos anuales, y el acceso a hábitats de buena calidad es crucial para el cumplimiento de la migración. La pérdida y degradación de los hábitats naturales puede estar contribuyendo a la disminución global de las poblaciones. Las aves playeras frecuentemente se alimentan y descansan en tierras agrícolas, pero el uso de éstas puede estar aumentando el riesgo a la exposición a pesticidas inhibidores de la colinesterasa $(\mathrm{ChE})$. Organofosforados $(\mathrm{OP})$ y carbamatos (CB) son inhibidores de la ChE comunes y la exposición a éstos compuestos puede causar una serie de efectos sub-letales o incluso la muerte. Para evaluar la exposición de las aves playeras migratorias a los pesticidas, se tomaron muestras de las aves en los sitios de parada migratoria durante los movimientos hacia el norte y sur en Norteamérica y en las áreas no reproductivas en Sudamérica. Se comparó la actividad de la colinesterasa y la masa corporal de los individuos capturados en sitios de referencia donde no se aplica OP o CB versus sitios agrícolas donde la utilización de productos para el control de plagas en los cultivos es recomendada. Los niveles de actividad de la acetilcolinesterasa plasmática (AChE) y la butirilcolinesterasa (BChE) de Tryngites subruficollis fueron menores en los sitios agrícolas en Sudamérica, indicando una exposición a pesticidas de OP y CB. Los resultados de las pruebas de reactivación de ChE en el plasma y los análisis de los lavados de patas no fueron concluyentes. Un meta análisis entre seis de las especies estudiadas indicó que el efecto de los tamaños fue negativo en cuatro de las seis especies y en una de las seis species para AChE y BChE, respectivamente, indicando efectos negativos

Manuscript received 5 February 2009; accepted 9 October 2009.

${ }^{6}$ Current address: PRBO Conservation Science, 3820 Cypress Drive \#11, Petaluma, CA 94954. E-mail: kmstrum@ksu.edu ${ }^{7}$ Current address: USGS Columbia Environmental Research Center, 4200 E. New Haven Road, Columbia, MO 65201.

The Condor, Vol. 112, Number 1, pages 15-28. ISSN 0010-5422, electronic ISSN 1938-5422. @ 2010 by The Cooper Ornithological Society. All rights reserved. Please direct all requests for permission to photocopy or reproduce article content through the University of California Press's Rights and Permissions website, http://www.ucpressjournals.com/ reprintInfo.asp. DOI: 10.1525/cond.2010.090026 


\begin{abstract}
de los químicos agrícolas sobre la actividad de ChE en un subconjunto de las especies. Las comparaciones de la masa corporal entre sitos y regiones sugirieron que el uso del hábitat no afecta la dinámica de la masa corporal. Este estudio presenta una de las primeras estimaciones prospectivas sobre la exposición de las aves playeras a pesticidas inhibidores de la ChE. Estos resultados sugieren que está ocurriendo una exposición baja a pesticidas inhibidores de la ChE en algunas áreas no reproductivas pero no en los sitios de parada durante la migración. Estudios futuros deberán abordar el uso del hábitat en las áreas no reproductivas de las aves playeras e identificar otros sitios y niveles de exposición potenciales.
\end{abstract}

\section{INTRODUCTION}

Continuing declines in populations of migratory shorebirds have spurred research to investigate possible environmental factors driving population dynamics rangewide. Exposure to environmental contaminants, habitat loss and degradation, disturbance, and illegal hunting have been suggested as anthropogenic factors that may be affecting shorebird populations (Senner and Howe 1984, Page and Gill 1994, Zöckler et al. 2003). Previous research on shorebirds' exposure to environmental contaminants has focused on heavy metals, organochlorines, and polychlorinated biphenyls (Burger et al. 1993, Hui et al. 2001, McFarland et al. 2002). Few studies have investigated exposure of migratory shorebirds to pesticides that act by inhibiting cholinesterase (ChE) enzymes (Mitchell and White 1982, Fair et al. 1995, Iko et al. 2003). Chemicals that inhibit $\mathrm{ChE}$ are potent insecticides widely used to control agricultural pests throughout North and South America. Of 11.8 million $\mathrm{kg}$ of insecticides applied to protect crops in the United States in 2006, 73\% were ChE-inhibiting organophosphorus (OP) and carbamate (CB) pesticides (NASS 2008). In the environment, $\mathrm{OP}$ and $\mathrm{CB}$ insecticides degrade rather rapidly but can be highly toxic over the short term and may pose a risk to non-target species such as birds. For example, thousands of migratory birds have been poisoned by OPs and CBs while feeding in agricultural areas in South America (Basili and Temple 1995, Goldstein et al. 1999a). In addition to direct mortality, sublethal exposure to OPs and CBs can cause a suite of physiological impairments including loss of migratory orientation and decreased flight speed (Vyas et al. 1995, Grue et al. 1997, Brasel et al. 2005).

The Great Plains region of the United States is an important flyway for migratory shorebirds that breed in arctic and north-temperate latitudes and winter in the southern cone of South America (Skagen et al. 1999). The Great Plains are now dominated by row crops and grazing for livestock production. Similarly, shorebirds' nonbreeding habitats in South America have largely been converted to farmland and rangeland (Soriano et al. 1992, Isacch and Martínez 2003, Blanco et al. 2006). Therefore, evaluation of migratory shorebirds' potential exposure to ChE-inhibiting pesticides is important to their conservation.

Life-history traits, including habitat preferences, food selection, and migratory pathways, may determine shorebirds' risk of pesticide exposure. Most shorebirds migrating between the Nearctic and Neotropical regions can be categorized by their habitat requirements as upland or wetland birds. Upland shorebirds, preferring drier habitats with vegetation of low stature, include the American Golden-Plover (Pluvialis dominica), Upland Sandpiper (Bartramia longicauda), and Buffbreasted Sandpiper (Tryngites subruficollis; Myers and Myers 1979, Isacch and Martínez 2003). These three species regularly use agricultural habitats at stopover and wintering sites where they may come into direct contact with OPs and CBs. Upland shorebirds consume a variety of invertebrates, including agricultural pests, which can be abundant during periods of crop production that coincide with migrants' arrival (Houston and Bowen 2001, Nagoshi and Meagher 2004, Isacch et al. 2005; K. M. Strum, unpubl. data). Wetland species, including the Least Sandpiper (Calidris minutilla), Pectoral Sandpiper (C. melanotos), and White-rumped Sandpiper (C. fuscicollis), require habitats with standing water and frequently use rice fields and other agricultural areas where use of $\mathrm{ChE}$ inhibitors is also widespread (Skagen and Knopf 1993, Twedt et al. 1998, Skagen et al. 2005, Blanco et al. 2006). In rice fields, mortality of shorebirds has been reported after the application of carbofuran, a potent anti-ChE agent (Flickinger et al. 1980, 1986, Littrell 1998).

The activity of ChE in brain or blood plasma is often measured as an indicator of exposure and the effects of OP and CB pesticides (Soler-Rodriguez et al. 1998). Measurement of ChE activity in the brain is invasive, requiring either finding dead birds or euthanizing them for analysis. Alternatively, ChE activity in plasma is sensitive to exposure to low doses of OPs and CBs and can be used to monitor sublethal exposure of birds captured alive (Hooper et al. 1989, Thompson 1991, Wilson et al. 1991, Soler-Rodriguez et al. 1998). There are two main types of $\mathrm{ChE}$ in avian plasma. Acetylcholinesterase (AChE) is the enzyme responsible for hydrolysis of the neurotransmitter acetylcholine and maintains proper functioning of the central and peripheral nervous systems. Butyrylcholinesterase (BChE) has been shown to successfully buffer some OP compounds from inhibiting AChE, although its exact physiological function remains unknown (Leopold 1996, Parker and Goldstein 2000).

Enzyme activity can be used to monitor exposure to OP and $\mathrm{CB}$ pesticides by comparison of samples taken in the field to reference values or by reactivation of inhibited enzymes (Hooper et al. 1989, Maul and Farris 2005, Strum et al. 2008). Evaluation of $\mathrm{OP}$ and $\mathrm{CB}$ exposure in migrant birds, however, must account for potential sources of variation that might affect 
transcontinental efforts to monitor ChE. For example, levels of plasma ChE can vary spatially and temporally, but reference values rarely provide adequate controls for these factors to be evaluated (Goldstein et al. 1999b). Similarly, attempts to reactivate $\mathrm{ChE}$ can be hampered by dealkylation and spontaneous reactivation of inhibited enzymes (Wilson et al. 1992). In this study, we evaluated exposure by comparing ChE activities in samples taken from birds at matched sites in the same hemisphere and by storing all samples at ultra-low temperatures before analysis (Hunt and Hooper 1993).

The purpose of our study was to evaluate migratory shorebirds' exposure to ChE-inhibiting pesticides. We sampled shorebirds at migratory stopover sites in North America and at nonbreeding sites in South America. Strum et al. (2008) reported baseline reference values and variability of plasma ChE activity for nine species of migratory shorebirds sampled at pesticide-free stopover sites in the Great Plains. Here, we provide the first assessments of plasma $\mathrm{ChE}$ activities for nonbreeding shorebirds in South America, and we compare plasma ChE activity and body mass at sites without OP and $\mathrm{CB}$ use to those in agricultural areas where $\mathrm{ChE}$ inhibitors were recommended for pest control. We calculated an effect size of anti-ChE pesticides on ChE activity across all species to assess the magnitude of the effect of OPs and CBs on $\mathrm{ChE}$ activity. If shorebirds were exposed to pesticides, we predicted activity of plasma $\mathrm{ChE}$ and mean body mass would be lower in samples of birds from sites where insecticides were used (Grue et al. 1997, Goldstein et al. 1999b). We conducted reactivation assays and analyzed samples washed from the birds' feet as potential additional lines of evidence to corroborate exposure to $\mathrm{OP}$ and $\mathrm{CB}$ pesticides. Our study represents the first large-scale, prospective evaluation of exposure to anti-ChE pesticides as a first step toward identifying potential conservation threats to migratory shorebirds throughout their range (Hooper et al. 2003).

\section{METHODS}

\section{SHOREBIRD CAPTURE}

In the Central Flyway of the United States, we captured shorebirds in three states (Texas, Kansas, and Nebraska) from April to August 2006 (north- and southbound migration) and from March to June 2007 (northbound). In South America, we captured birds in three countries (Argentina, Paraguay, and Uruguay) from September to December 2006. We concentrated these efforts at reference sites, protected natural areas where pesticide use was prohibited, and agricultural sites, where OPs and CBs were recommended for pest control according to national or state agricultural guidelines. Pesticide use was not documented at all sites, but anti-ChE chemicals are applied annually (Fagerness et al. 2001, Blanco et al. 2006, Way and Cockrell 2007).

During northbound migration in 2006, the four reference sites were coastal prairie and rice fields at Anahuac National
Wildlife Refuge, Chambers County, Texas ( $\left.29^{\circ} 34^{\prime} \mathrm{N}, 94^{\circ} 32^{\prime} \mathrm{W}\right)$, salt marshes at Quivira National Wildlife Refuge, Stafford County, Kansas ( $\left.38^{\circ} 08^{\prime} \mathrm{N}, 98^{\circ} 29^{\prime} \mathrm{W}\right)$, native grasslands at Konza Prairie Biological Station, Riley County, Kansas (39 $04^{\prime} \mathrm{N}, 96^{\circ} 33^{\prime} \mathrm{W}$ ), and wetlands at Kissinger Wildlife Management Area, Clay County, Nebraska $\left(40^{\circ} 26^{\prime} \mathrm{N}, 98^{\circ} 06^{\prime} \mathrm{W}\right)$. Rice production at Anahuac was strictly organic, and at Quivira application of pesticides was not permitted within the national wildlife refuge (M. Whitbeck, pers. comm.; USEPA 2006). Konza Prairie and Kissinger are natural reserves that are also free of pesticides (E. Horne and R. Souerdyke, pers. comm.). During southbound migration in 2006 and northbound migration in 2007, shorebirds were sampled at one reference site, salt marshes of Bolivar Flats Shorebird Sanctuary, Galveston County, Texas $\left(29^{\circ} 78^{\prime} \mathrm{N}, 94^{\circ} 77^{\prime} \mathrm{W}\right)$ and three agricultural sites, turf-grass farms near Lawrence, Douglas County, Kansas ( $38^{\circ} 58^{\prime}$ N, $95^{\circ} 14^{\prime} \mathrm{W}$ ), Colwich, Sedgwick County, Kansas ( $37^{\circ} 46^{\prime} \mathrm{N}, 97^{\circ} 32^{\prime} \mathrm{W}$ ), and Crosby, Harris County, Texas $\left(29^{\circ} 54^{\prime} \mathrm{N}, 95^{\circ} 03^{\prime}\right.$ W; Fig. 1).

In South America, three reference sites were inundated grasslands along the shoreline of Bahía de Asunción, Asunción, Paraguay $\left(25^{\circ} 16^{\prime} \mathrm{S}, 57^{\circ} 37^{\prime} \mathrm{W}\right)$, salt marshes and shoreline of Laguna Mar Chiquita, Cordoba, Argentina ( $30^{\circ} 32^{\prime} \mathrm{S}$, $62^{\circ} 17^{\prime} \mathrm{W}$ ), and coastal grasslands of Laguna de Rocha, Departamento Rocha, Uruguay ( $\left.34^{\circ} 40^{\prime} \mathrm{S}, 54^{\circ} 17^{\prime} \mathrm{W}\right)$. Bahía de Asunción and Laguna Mar Chiquita are designated as sites of regional and hemispheric importance for shorebirds by the Western Hemisphere Shorebird Reserve Network. Bahía de Asunción is centrally located within the city of Asunción with no adjacent agriculture. Laguna Mar Chiquita and Laguna de Rocha are nationally protected parks, in neither of which were OPs or CBs applied during the field season (H. Caimarys and E. Martin, pers. comm.). The two agricultural sites were estancias with rice fields and cattle pastures near San Joaquin, Santa Fe Province, Argentina ( $\left.30^{\circ} 42^{\prime} \mathrm{S}, 60^{\circ} 52^{\prime} \mathrm{W}\right)$ and Coronilla, Departamento Rocha, Uruguay $\left(33^{\circ} 48^{\prime} \mathrm{S}, 53^{\circ} 39^{\prime} \mathrm{W}\right.$; Fig. 1).

Shorebirds were captured alive with mist nets, drop nets, and night lighting under applicable state, federal, and international permits. Handling and sampling were done under protocols approved by the Kansas State University Animal Care and Use Committee. In addition, a small number of Buffbreasted Sandpipers were collected by shotgun at two turfgrass farms near Lawrence and Colwich as part of a separate study of avian influenza. Collected birds were prepared as study skins and archived at the Museum of Natural History at the University of Kansas (Robbins 2007).

\section{SAMPLE COLLECTION AND PREPARATION}

To compare the birds' body size and condition by site, we recorded seven measurements of each individual. Mass of livecaptured birds was measured with a Pesola spring scale $( \pm 1 \mathrm{~g})$. Length of the flattened and straightened wing was measured 

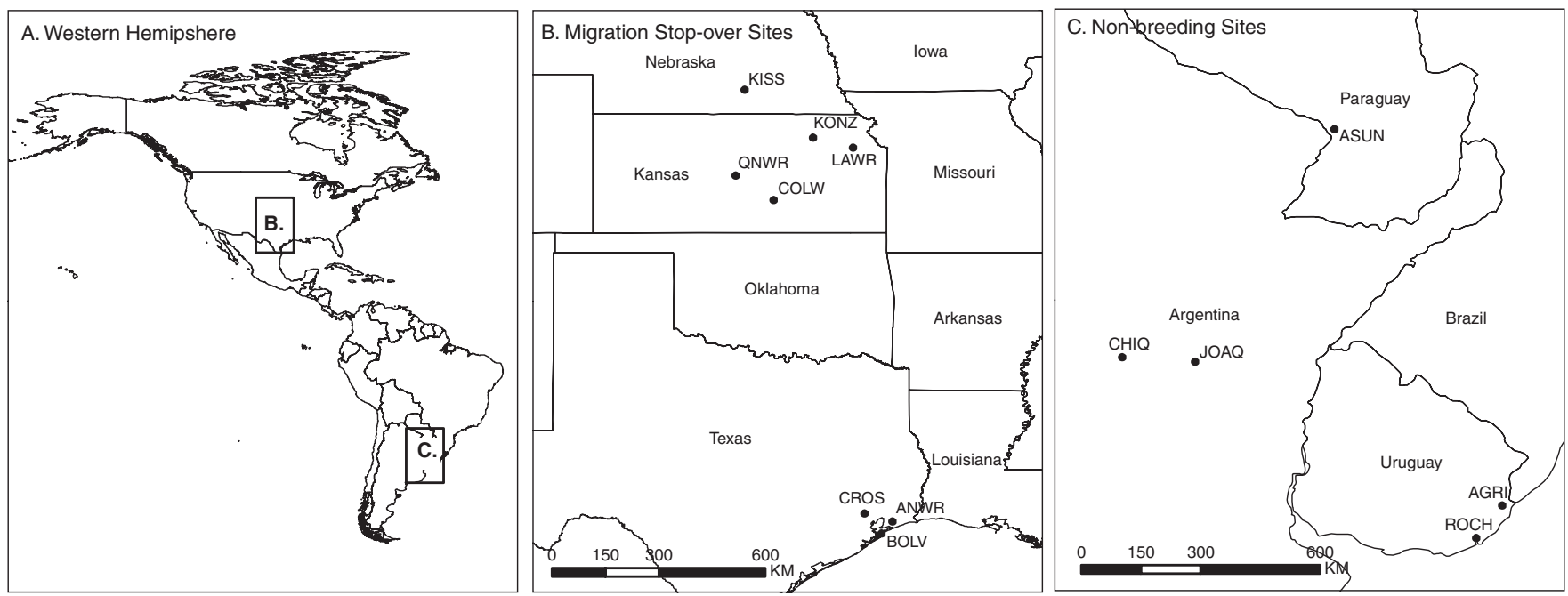

FIGURE 1. (A) Location of sampling sites in the Western Hemisphere. (B) Migratory stop-over sites sampled in the Northern Hemisphere. Reference sites: ANWR, Anahuac National Wildlife Refuge; BOLV, Bolivar Flats Shorebird Sanctuary; KISS, Kissinger Wildlife Management Area; KONZ, Konza Prairie: QNWR, Quivira National Wildlife Refuge. Agricultural sites (turf-grass farms): COLW, near Colwich, Kansas; CROS, near Crosby, Texas; LAWR, near Lawrence, Kansas. (C) Nonbreeding sites in the Southern Hemisphere. Reference sites: ASUN, Bahía de Asunción, Paraguay; CHIQ, Laguna Mar Chiquita, Argentina; ROCH, Laguna de Rocha, Uruguay. Agricultural sites (rice fields): AGRI, near Coronilla, Uruguay; JOAQ, near San Joaquin, Argentina.

with a wing rule $( \pm 0.5 \mathrm{~mm})$. Total head, culmen, and tarsus length were measured with vernier calipers $( \pm 0.1 \mathrm{~mm})$. Fat deposits in the furcular region, sides, and abdomen, were visually scored on a 9-point scale from 0 to 8 , with 0 indicating no fat and 8 indicating large fat depots (Bairlein 1995). Dimorphic species were sexed in the field according to Prater et al. (1977). All birds were fitted with a U.S. Fish and Wildlife Service metal band with a unique number.

Samples taken for evaluation of pesticide exposure included blood, brain tissue, and foot washes. Blood was collected with a 27-gauge needle and heparinized capillary tubes $(0.07 \mathrm{~mL})$ from the brachial vein of the wing. Total blood collected per bird ranged from two to six capillary tubes $(0.14$ to $0.42 \mathrm{~mL}$ ) and was $<1 \%$ of the bird's body mass (Gaunt et al. 1999). Blood samples were transferred to $0.5-\mathrm{mL}$ screwcap cryovials, stored on wet ice in the field, and centrifuged within $8 \mathrm{hr}$ to separate plasma from red blood cells. Plasma samples were stored frozen in liquid nitrogen for 1 to 4 weeks and then transferred to storage at $-80{ }^{\circ} \mathrm{C}$ until analyzed in the laboratory. Collected birds were wrapped in acetone-rinsed foil, placed on wet ice in the field, and frozen at $-80{ }^{\circ} \mathrm{C}$ within $8 \mathrm{hr}$. Brains were excised partially frozen, placed into $2.0-\mathrm{mL}$ Eppendorf tubes, and immediately refrozen at $-80^{\circ} \mathrm{C}$. The tarsi and feet of a subset of captured and collected individuals were rinsed with $15 \mathrm{~mL}$ pesticide-grade 2-propanol. Residues were collected with a stainless steel funnel into an amber glass jar with a Teflon-lined lid. Foot-wash samples were stored on wet ice in the field and transferred to $-20^{\circ} \mathrm{C}$ until analyzed. All samples were analyzed within one year of collection.

\section{ChE ACTIVITY}

ChE activity was analyzed at the Institute for Environmental and Human Health at Texas Tech University and at the Division of Biology at Kansas State University. Samples analyzed at Texas Tech were read on a SpectraMax plate reader (Molecular Devices, Palo Alto, CA) with Softmax Pro software (Molecular Devices). Samples stored at Kansas State were analyzed with a Model 680 microplate reader (Bio-Rad Laboratories, Hercules, CA) and Microplate Manager software (version 5.2.1, Bio-Rad Laboratories). Assay conditions and reagent concentrations at the two laboratories were identical. To quantify the variation within and between labs, aliquots of horse serum (Invitrogen Corporation, Carlsbad, CA) of known ChE activity were run as standards on each plate containing shorebird samples.

Sample preparation differed by tissue type. Plasma samples were thawed immediately before analysis and diluted to a species-specific concentration with cold buffer, $0.5 \mathrm{M}, \mathrm{pH} 7.4$. Brains were thawed and homogenized with the Tissue Miser electric homogenizer (Fisher Scientific, Pittsburgh, PA) at a 1:3 ratio of tissue to buffer. ChE activity was determined immediately after homogenization on a sample serially diluted 60- or 72-fold.

ChE activities for plasma and brain were determined by the method of Ellman et al. (1961) as modified by Gard and Hooper (1993) for use on a 96-well plate reader and by Strum et al. (2008) for shorebirds. The final volume of each assay was $250 \mu \mathrm{L}$ and contained the following components in $0.05 \mathrm{M}$ Trizma buffer ( $\mathrm{pH} 8.0$ ): $3.23 \times 10^{-4} \mathrm{M}$ final concentration of 5,5'-dithiobis(2-nitrobenzoic acid), diluted enzyme 
sample, and $1.00 \times 10^{-3} \mathrm{M}$ final concentration of acetylthiocholine iodide (AThCh). To separate activity of $\mathrm{BChE}$ from that of AChE, we incubated a portion of each sample with the BChE-specific inhibitor tetraisopropyl pyrophosphoramide (iso-OMPA) at a final concentration $1.00 \times 10^{-4} \mathrm{M}$. BChE activity was calculated as the difference between total cholinesterase $(\mathrm{TChE}=\mathrm{AChE}+\mathrm{BChE})$ measured without iso-OMPA and $\mathrm{AChE}$ activity in the presence of iso-OMPA. All samples were run in triplicate at $25{ }^{\circ} \mathrm{C}$ with the spectrophotometer set in kinetic mode. Absorbance was measured at $412 \mathrm{~nm}$ at 15 -sec intervals for $180 \mathrm{sec}$ with a lag time of $0 \mathrm{sec}$. The mean of triplicate $\mathrm{ChE}$ analyses for each sample was converted from absorbance units per minute to $\mu$ moles AThCh hydrolyzed per minute (units) with an extinction coefficient of $13600(\mathrm{~cm} \times$ $\mathrm{M})^{-1}$ and were expressed as units $\mathrm{mL}^{-1}$ of plasma or units $\mathrm{g}^{-1}$ of brain tissue.

\section{REACTIVATION ASSAYS}

In cases where plasma ChE activity is lower in samples collected from agricultural sites than in those from reference sites, in vitro reactivation of plasma ChEs can provide further evidence of exposure to $\mathrm{ChE}$ inhibitors. Mean plasma $\mathrm{ChE}$ activity was lower at agricultural sites than at reference sites for one species, the Buff-breasted Sandpiper, and we performed reactivation assays on samples from this species if their volume after dilution $(\geq 1.3 \mathrm{~mL})$ was adequate. Attempts to reactivate OP-inhibited enzyme required two aliquots of diluted sample. One aliquot was incubated with $1.00 \times 10^{-4} \mathrm{M}$ final concentration of pyridine-2-aldoxime methochloride (2-PAM) at $25^{\circ} \mathrm{C}$ to induce chemical reactivation. The remaining aliquot received an equal volume of distilled water and was incubated alongside the sample with 2-PAM as a negative control. Aliquots were assayed after $0.5 \mathrm{hr}$. Reactivation assays for $\mathrm{CB}$ inhibition of enzyme required an additional pair of aliquots of diluted sample. One aliquot was incubated at $37^{\circ} \mathrm{C}$ to induce spontaneous reactivation; the other was maintained on ice as a negative control. Both aliquots were assayed after $1 \mathrm{hr}$.

\section{CHEMICAL-RESIDUE ANALYSES}

Foot-wash samples were screened for 13 OPs and nine CBs at a detection limit of $0.5 \mu \mathrm{g} \mathrm{mL}{ }^{-1}$. OP residues were analyzed on an HP 6890 gas chromatograph equipped with a nitrogenphosphorous detector. The column (J \& W Scientific, Rancho Cordova, CA) was a fused silica capillary, internal diameter $30 \mathrm{~m} \times 0.25 \mathrm{~mm}$, coated with a DB-1701 stationary phase (film thickness of $0.25 \mu \mathrm{m}$ ) and a flow rate of carrier gas $(\mathrm{He})$ of $1.5 \mathrm{~mL} \mathrm{~min}^{-1}$. Injector and detector temperatures were $250{ }^{\circ} \mathrm{C}$ and $275^{\circ} \mathrm{C}$, respectively. $\mathrm{CB}$ residues were analyzed on an HP 1100 Series liquid chromatograph with a Post-Column Derivatizer (PCX) 5200 (Mountain View, CA) and a fluorescence detector (excitation and emission wavelengths of 330 and $465 \mathrm{~nm}$, respectively). The column (Discovery $\mathrm{C}_{8}, \mathrm{Su}-$ pelco, St. Louis, MO) was $250 \mathrm{~mm} \times 4.6 \mathrm{~mm}$ (particle size
$5 \mu \mathrm{m}$ ) operated at a flow rate of $0.8 \mathrm{~mL} \mathrm{~min}^{-1}$. The gradient was with a water:methanol ratio of 88:12 for 2 min, followed by an increase in methanol to $34: 66$ over $40 \mathrm{~min}$ with a hold time of $4 \mathrm{~min}$, followed by an increase to $100 \%$ methanol in $0.1 \mathrm{~min}$ with a final hold time of $3 \mathrm{~min}$ and a 12-min equilibration time.

In analyses by both gas and liquid chromatography, internal standards adjusted for some of the internal variation of the instrument. Additional quality-control measures included an intermittent standard run after every five injections. If the intermittent standard differed by more than $10 \%$, the sample set was reanalyzed. Though we used internal standards to correct for any matrix variability, we calculated sample concentrations with external standards. A five-point standard curve was constructed from constant-volume injections of calibration standards. Computer-generated peak areas were then used to measure sample concentrations relative to the external standards.

\section{STATISTICAL ANALYSES}

We did statistical analyses with the program SAS (version 9.1.3, SAS Institute, Cary, NC), our meta-analysis with the program MetaWin (version 2.0, Sinauer Associates, Sunderland, MA). We considered results of statistical tests significant at $\alpha \leq 0.05$ and report estimates \pm SD unless noted.

Much of birds' variation in plasma $\mathrm{ChE}$ activity is due to variation in body size, and we analyzed each species of shorebird separately (Roy et al. 2005, Strum et al. 2008). We used $Z$-tests to identify outliers on the basis of observations that were greater than $\pm 3 \mathrm{SD}$ of the overall mean for the species. Two Least Sandpipers had BChE activity levels $>15$ SD of the mean for this species and were omitted from statistical analyses (Strum et al. 2008). We compared ChE activities by hemisphere (North vs. South America) to investigate temporal variation, and we compared reference sites and agricultural sites within each hemisphere to test for a potential effect of agricultural chemicals. Exposure to OP and CB pesticides can result in decreased body mass (Grue 1982, Grue et al. 1997), so we tested for an effect of $\mathrm{ChE}$ inhibition. Fat scores were significantly correlated with body mass in 7 of 13 species $\left(r^{2}\right.$ $\geq 0.4, P \leq 0.05$ ), and we used body mass as an index of body condition and compared mean body mass by hemisphere and by treatment (site) within a hemisphere with independent two-tailed $t$-tests (Proc TTEST). Comparisons of differences between hemispheres were calculated with data from reference sites to avoid the potential confounding effects of dietary changes between hemispheres that may affect ChE activity (Goldstein et al. 1999b).

Despite considerable effort, we were unable to capture all species at every combination of hemisphere and treatment, so we can not use factorial models. Therefore, to synthesize the effect of treatment (reference vs. agriculture) on ChE activity in shorebirds, we calculated species, hemisphere, and 
cumulative effect sizes, using Hedges' $d$ as a measure of effect size (Gurevitch and Hedges 1993). Our meta-analysis quantified an overall effect of the treatment (reference vs. agriculture) on a response variable (ChE activity) for five species. Lower ChE activity indicates potential exposure to anti-ChE pesticides. The magnitude of the effect size $(d)$ is unbounded and can be positive or negative. According to Cohen (1988), values of $d \leq 0.2$ are small, $d=0.5$ are moderate, and $d \geq 0.8$ indicate a large effect. We used reference sites as the control, and negative values indicate that individuals captured at agricultural sites had lower $\mathrm{ChE}$ activity than did birds sampled at reference sites.

We evaluated ChE reactivation with paired two-tailed $t$-tests (Proc TTEST). To evaluate reactivation of OP-inhibited enzyme, we compared post-incubation ChE activity of the sample incubated with 2-PAM versus the negative control. Similarly, to test for reactivation of enzyme inhibited by $\mathrm{CBs}$, we compared the post-incubation activity of the incubated sample versus the sample kept on wet ice. To be considered positive for a successful reactivation, the ChE activity of the incubated sample must be greater than that of the control. Some sample volumes were not sufficient for reactivation analyses of both OPs and CBs, resulting in unequal sample sizes for the two assays.

\section{RESULTS}

We sampled 631 individuals of 12 species (10 latitudinal migrants, 2 neotropical endemics) at migratory stopover sites and nonbreeding sites in the Western Hemisphere (see Table 1 for scientific names). The number of individuals captured per species ranged from three (Wilson's Snipe and South American Snipe) to 122 (White-rumped Sandpiper).

Of the birds captured, 452 yielded volumes of plasma sufficient for analyses of ChE activity (Tables 2 and 3). In South
America, mean AChE activity (units $\mathrm{mL}^{-1}$ plasma) per species sampled from reference sites ranged from a low of $0.31 \pm$ 0.08 (South American Snipe) to $0.61 \pm 0.20$ (Lesser Yellowlegs) and mean BChE activity per species ranged from 0.89 \pm 0.17 (South American Painted-snipe) to $4.38 \pm 1.23$ (Lesser Yellowlegs). In North America, we found that mean AChE activity sampled from reference sites ranged from a low of $0.27 \pm 0.20$ (Upland Sandpiper) to $0.73 \pm 0.37$ (White-rumped Sandpiper) and mean BChE activity ranged from a low of $1.63 \pm 0.61$ (Upland Sandpiper) to $8.34 \pm 4.54$ (Semipalmated Sandpiper).

\section{ChE ACTIVITY}

Differences in plasma ChE activities by treatment (reference vs. agriculture) were apparent in one of five species for which samples were sufficient for this comparison. In Buff-breasted Sandpipers, AChE and BChE activities were $37 \%\left(t_{21}=-2.3\right.$, $P=0.03)$ and $32 \%$ lower $\left(t_{21}=-2.9, P=0.008\right)$, respectively, at agricultural sites in South America (Table 2, Fig. 2, respectively). However, BChE activity was $21 \%$ higher in Buffbreasted Sandpipers sampled from agricultural sites in North America $\left(t_{39}=3.5, P \leq 0.001\right.$; Table 3, Fig. 2$)$. There were no further differences in $\mathrm{ChE}$ activity as a function of habitatspecific pesticide use in the five other species (Tables 2 and 3, Fig. 2)

$\mathrm{AChE}$ and $\mathrm{BChE}$ activity from reference sites differed by hemisphere in one of two species with data sufficient for comparisons (Tables 2 and 3, Fig. 3). Buff-breasted Sandpipers sampled at reference sites in North and South America did not differ in mean AChE or BChE activity. However, AChE activity of White-rumped Sandpipers was 19\% higher in individuals sampled in North America than in those from South America $\left(t_{97}=2.5, P=0.01\right)$. Similarly, mean BChE activity was $27 \%$ higher in Pectoral Sandpipers sampled in North

TABLE 1. Numbers $(n)$ of shorebirds captured in North and South America. See Tables 3 and 4 for number of individuals used in ChE analysis.

\begin{tabular}{lcc}
\hline \hline Species & North America $(n)$ & South America $(n)$ \\
\hline Nearctic-neotropical migrants & & \\
American Golden-Plover Pluvialis dominica & 3 & 47 \\
Lesser Yellowlegs Tringa flavipes & 3 & 6 \\
Upland Sandpiper Bartramia longicauda & 67 & - \\
Semipalmated Sandpiper Calidris pusilla & 60 & - \\
Least Sandpiper Calidris minutilla & 65 & - \\
Western Sandpiper Calidris mauri & 76 & 42 \\
White-rumped Sandpiper Calidris fuscicollis & 36 & 24 \\
Pectoral Sandpiper Calidris melanotos & 38 & - \\
Buff-breasted Sandpiper Tryngites subruficollis & 67 & 5 \\
Wilson's Snipe Gallinago delicata & 3 & 3 \\
South American endemics & & \\
South American Painted-snipe Nycticryphes semicollaris & - & \\
South American Snipe Gallinago paraguaiae & - & \\
\hline
\end{tabular}



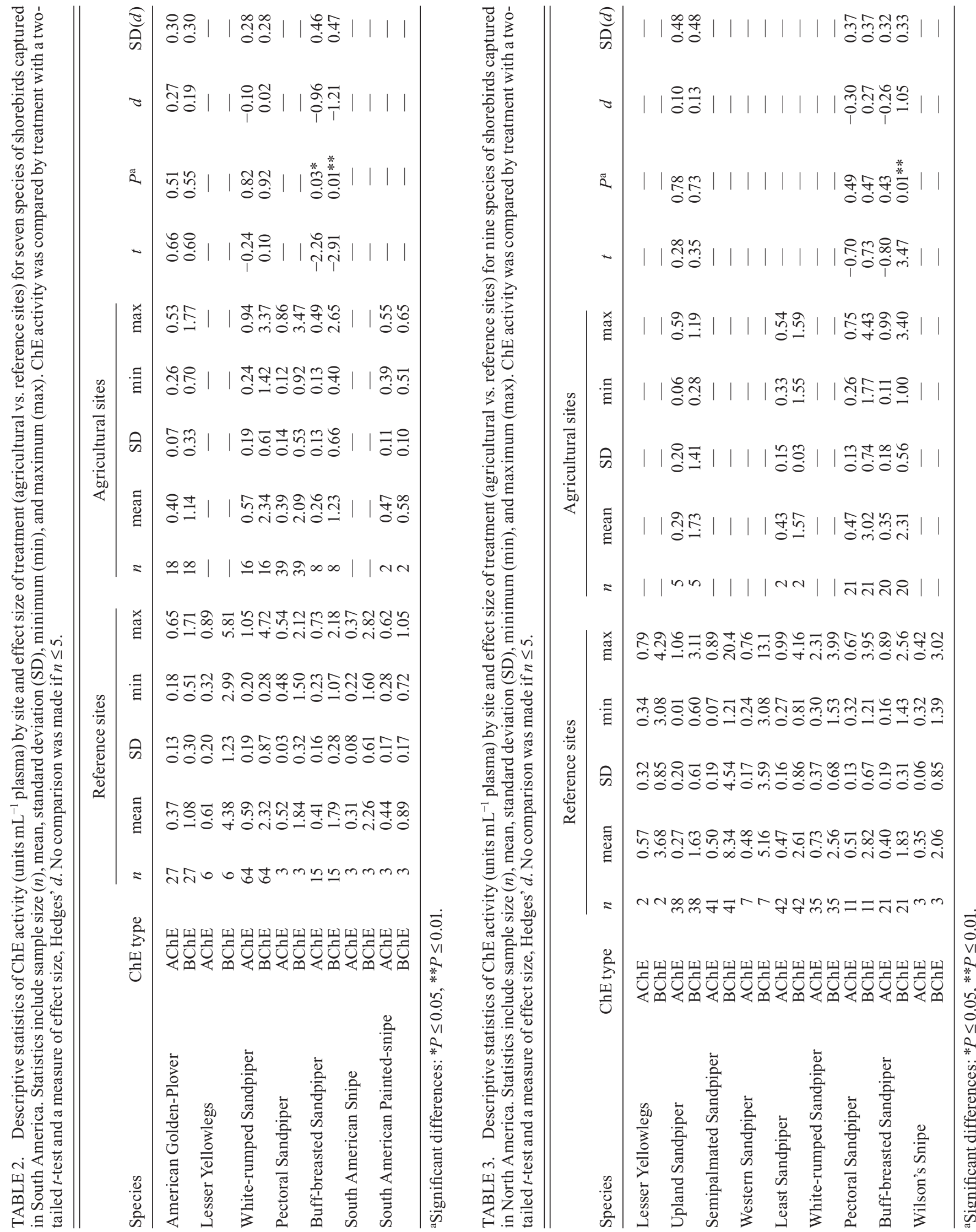

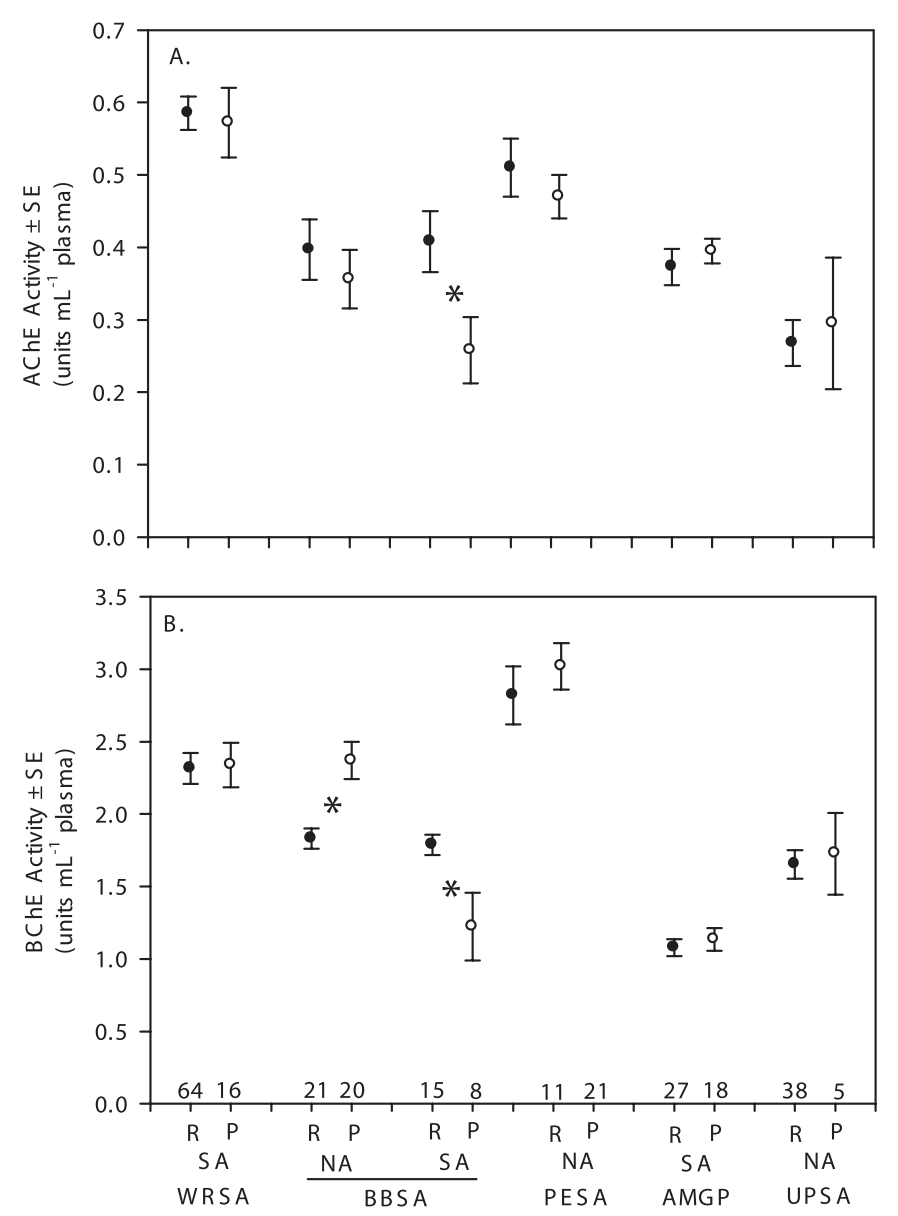

FIGURE 2. Effects on AChE (A) and BChE (B) activities of treatment (agricultural vs. reference) on five species of shorebirds captured in North and South America. Mean values (units $\mathrm{mL}^{-1}$ plasma) and standard errors (SE) of ChE activity in birds sampled from reference sites ( $\mathrm{R}$, closed circles) and agricultural sites (P, open circles). Treatment and hemisphere (NA, North America; SA, South America) are specified below the lower $x$ axis. Species are coded as WRSA, White-rumped Sandpiper; BBSA, Buff-breasted Sandpiper; PESA, Pectoral Sandpiper; AMGP, American Golden-Plover; UPSA, Upland Sandpiper. Sample sizes are specified above the lower $x$ axis. An asterisk (*) denotes a significant difference between $\mathrm{ChE}$ means according to a two-tailed $t$-test with $\alpha \leq 0.05$.

America than in those from South America, but statistical inferences were not possible because of small sample sizes.

Our meta-analysis quantified the effect of treatment (reference vs. agriculture) on ChE activity in five species of shorebirds. The cumulative effect sizes were not significant for the activity of $\operatorname{AChE}(d=-0.15,95 \% \mathrm{CI}:-0.45$ to +0.09$)$ or BChE $(d=0.18,95 \% \mathrm{CI}:-0.27$ to +0.61$)$. At a hemispheric level, in North America there was a significant negative effect of treatment on AChE activity $(d=-0.20,95 \% \mathrm{CI}:-0.30$ to $-0.08)$ and a positive effect on BChE activity $(d=+0.58,95 \%$ CI: +0.13 to +0.87$)$. In South America, there was no significant effect at a hemispheric level on AChE activity $(d=-0.11$,
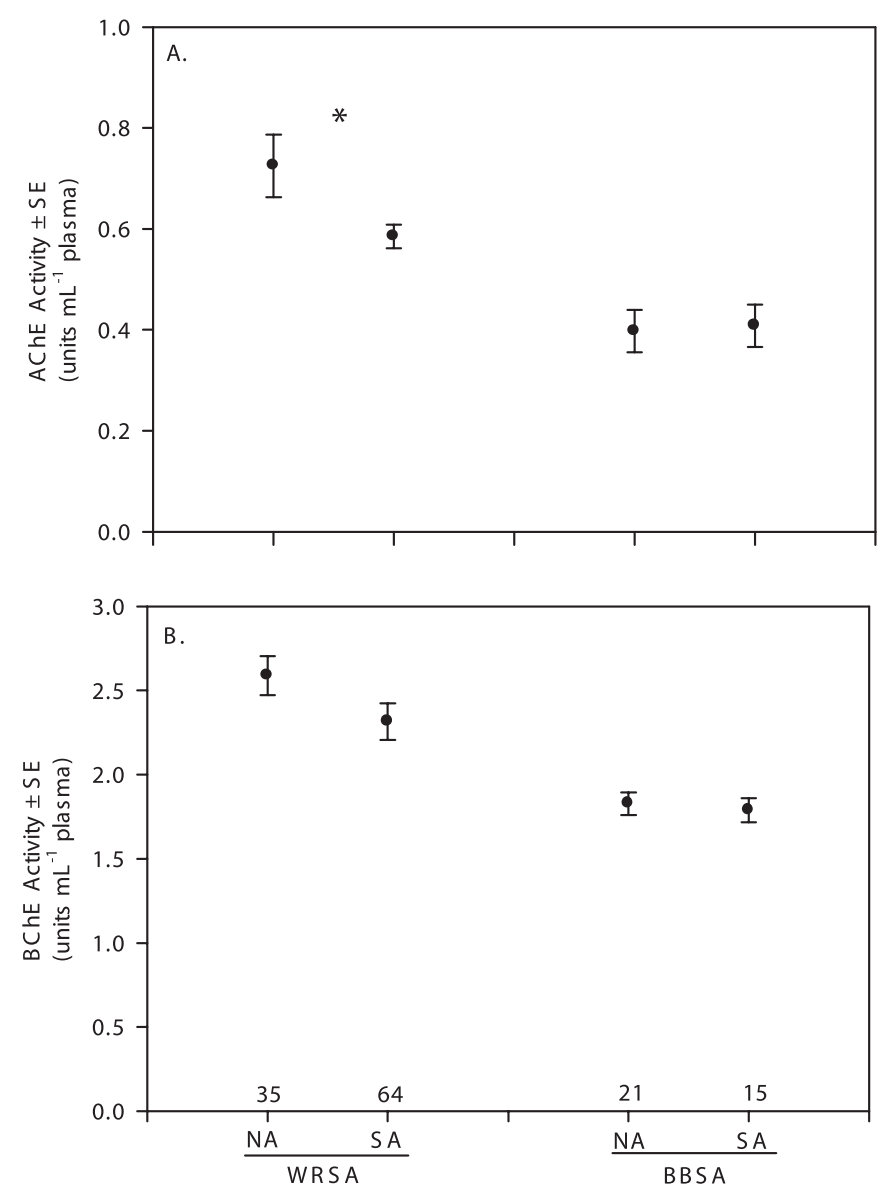

FIGURE 3. Influence of hemisphere on $\mathrm{AChE}$ (A) and BChE (B) activities in the White-rumped Sandpiper (WRSA) and Buffbreasted Sandpiper (BBSA), as expressed by mean values (units $\mathrm{mL}^{-1}$ plasma) and standard errors (SE) of ChE activity from individuals sampled from reference sites. Hemisphere (NA, North America; SA, South America) and species are specified below the lower $x$ axis, sample sizes above the lower $x$ axis. An asterisk (*) denotes a significant difference between $\mathrm{ChE}$ means according to a two-tailed $t$-test with $\alpha \leq 0.05$.

95\% CI: -0.47 to +0.27$)$ or BChE activity $(d=-0.11,95 \%$ CI: -1.21 to +0.13). Species-specific effect sizes for AChE activity were negative for four of six comparisons by treatment and ranged from a low of -0.96 in Buff-breasted Sandpipers to +0.27 in American Golden-Plovers, both sampled in South America (Tables 2 and 3). Effect sizes for BChE activity were negative for one of six comparisons and ranged from -1.21 in Buff-breasted Sandpipers captured in South America to +1.05 in Buff-breasted Sandpipers captured in North America (Tables 2 and 3). On the basis of the $Q_{w}$ statistic for heterogeneity, BChE effect sizes varied by species in South America $\left(Q_{w}=6.64, P=0.04\right)$ but not in North America $\left(Q_{w}=3.52\right.$, $P=0.17)$. There was no heterogeneity among species in effect sizes for AChE activity in North or South America (NA: $Q_{w}=$ $0.51, P=0.78$; SA: $Q_{w}=4.93, P=0.08$ ). 
Mean TChE activity in brains of Buff-breasted Sandpip-

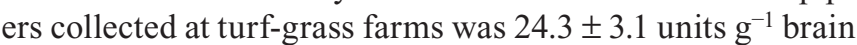
$(n=6$; range $=18.5$ to 27.5$)$. Mean TChE activity in plasma of Buff-breasted Sandpipers sampled at agricultural sites in North America was $2.7 \pm 0.6$ units $\mathrm{mL}^{-1}$ plasma $(n=20)$ and was $11 \%$ of brain TChE activity. The coefficient of variation $(12.8 \%)$ and variability between extreme values $(1.5 \times)$ in TChE activity in Buff-breasted Sandpiper brain were consistent with those documented by Hill (1988) for TChE activities in brains of wild birds.

\section{BODY MASS}

For five species data were sufficient for comparisons of body mass by hemisphere and treatment. In two of three species tested in South America, body mass at treatment and reference sites differed, and all three species tested in North America differed by site (Table 4). In South America, Buff-breasted Sandpipers were $10 \%$ heavier $\left(t_{22}=2.5, P=0.02\right)$ and Whiterumped Sandpipers were $6 \%$ heavier at agricultural sites $\left(t_{84}=2.3, P=0.03\right)$ than at reference sites, while in the American Golden-Plover $\left(t_{45}=1.4, P=0.17\right)$ mean body mass did not vary by site of capture. In the Northern Hemisphere, Buffbreasted Sandpipers were 10\% heavier $\left(t_{62}=2.4, P=0.02\right)$ and Pectoral Sandpipers were $31 \%$ heavier $\left(t_{35}=4.2, P \leq 0.001\right)$ at agricultural sites than at reference sites. Upland Sandpipers were $17 \%$ lighter at agricultural sites than reference sites $\left(t_{65}=-1.9, P=0.06\right)$.

In two of three species tested the mean body mass of birds from reference sites in one hemisphere differed from that of birds in the other hemisphere; in all cases, the body mass of individuals sampled during migration in North America was greater (Table 4). White-rumped Sandpipers were 7\% heavier $\left(t_{104}=3.2\right.$, $P \leq 0.01)$ and Buff-breasted Sandpipers were $13 \%$ heavier $\left(t_{35}=\right.$ $3.5, P \leq 0.001)$ in North America than in South America.

\section{PLASMA REACTIVATIONS}

We attempted to reactivate plasma ChE in samples collected from Buff-breasted Sandpipers in South America. Not all samples had volume adequate for reactivation analyses; 12 samples from reference sites and 5 samples from agricultural sites were tested for reactivation of plasma ChE activity. The 2-PAM method did not reactivate plasma $\mathrm{AChE}$ and $\mathrm{BChE}$ of Buff-breasted Sandpipers in samples collected from agricultural sites (AChE: $t_{4}=-0.8, P=0.46$; BChE: $t_{4}=0.6, P=0.59$ ) or reference sites (AChE: $t_{11}=1.8, P=0.09$; BChE: $t_{11}=2.5$, $P=0.03)$. Likewise, plasma ChEs did not reactivate spontaneously in samples collected from agricultural sites (AChE: $t_{4}=0.3, P=0.79$; BChE: $t_{4}=1.1, P=0.35$ ) or reference sites (AChE: $t_{10}=1.5, P=0.17$; BChE: $t_{10}=9.5, P \leq 0.001$ ).

\section{FOOT-WASH EXTRACTIONS}

We analyzed 256 foot-wash samples for 22 types of OP and $\mathrm{CB}$ residues. We collected 96 samples at reference sites $(9$ in

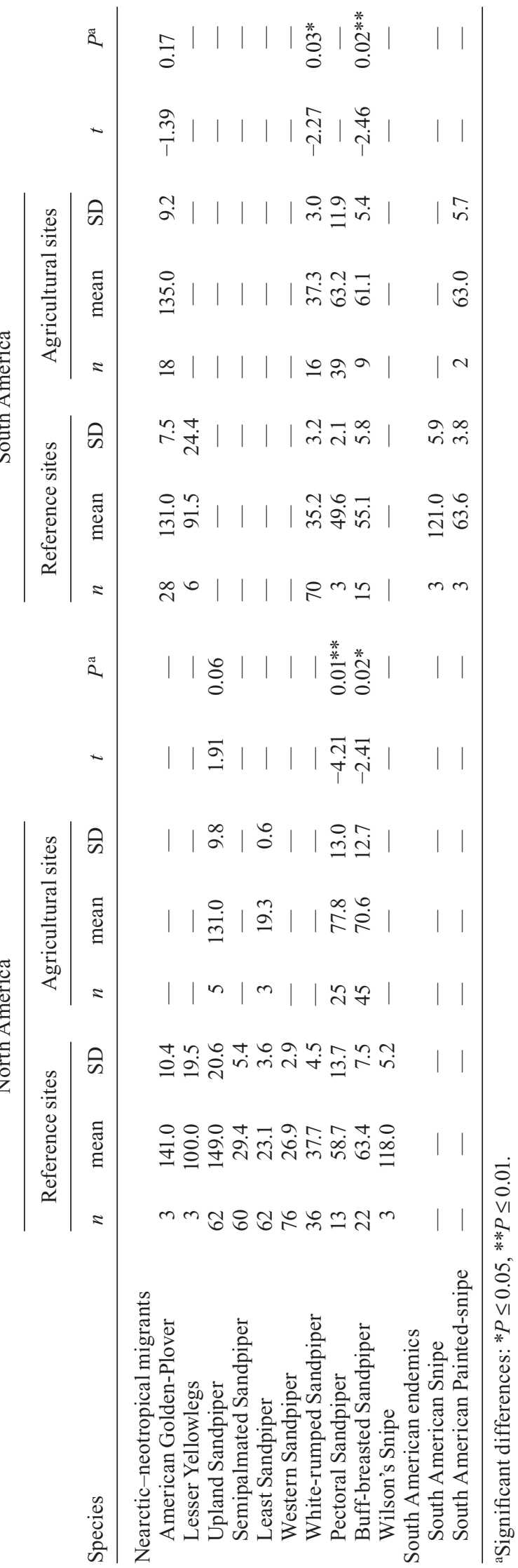


North America and 87 in South America) and 160 at agricultural sites (71 in North America and 89 in South America). Buff-breasted Sandpipers with decreased ChE activity sampled at agricultural sites in South America were included in these analyses. Chemical residues were not detected in any foot-wash samples (detection threshold of $0.5 \mu \mathrm{g} \mathrm{mL}^{-1}$ ).

\section{DISCUSSION}

We sampled intensively five species of migratory shorebirds across the Western Hemisphere to evaluate potential exposure to ChE-inhibiting pesticides and collected samples for baseline ChE assessments from an additional seven species. We used plasma ChEs to evaluate exposure because the sampling procedure is nonlethal and is sensitive for detection of most OP and CB pesticides (Soler-Rodriguez et al. 1998). Of three species for which data were sufficient for comparisons of reference sites and agricultural sites, one, the Buff-breasted Sandpiper, was likely exposed to ChE-inhibiting pesticides at a nonbreeding site in South America. Two other species, the American Golden-Plover and White-rumped Sandpiper, did not show evidence of exposure, i.e., lower activity of plasma ChE. In three species of shorebirds captured during migration in North America, evidence of exposure to ChE inhibitors was limited. A meta-analysis suggested the treatment's effect is negative because birds sampled in agricultural areas had depressed levels of AChE activity in four of six comparisons and BChE activity in one species was depressed. Although there was a significant negative effect of treatment on $\mathrm{AChE}$ in North America, there was a positive effect on BChE. Comparisons of body mass yielded no evidence of negative physiological effects due to ChE-inhibitor exposure or use of agricultural areas. We report the first reference values of ChE activity for seven species of shorebirds captured in South America, including two endemic species, the South American Snipe and the South American Painted-snipe.

\section{PLASMA CHE ACTIVITY}

Plasma ChEs differed by treatment area (reference vs. agriculture) only in the Buff-breasted Sandpiper. In South America, mean AChE and BChE activities in plasma of Buff-breasted Sandpipers were lower at agricultural sites than at reference sites, and the magnitude of the differences was consistent with patterns of inhibition caused by $\mathrm{ChE}$ inhibitors reported in other species of migratory birds (Goldstein et al. 1999a). Unexpectedly, BChE activity of Buff-breasted Sandpipers sampled at agricultural sites in North America was $21 \%$ higher than in those sampled at reference sites. The latter result is opposite the pattern predicted if the birds were exposed to $\mathrm{ChE}$ inhibitors but is consistent with post-exposure increases in TChE observed in laboratory experiments (Fleming and Bradbury 1981, Soler-Rodriguez et al. 1998). Iko et al. (2003) also offered post-exposure enzyme regeneration as a possible explanation for similar differences in TChE activity reported for the Mountain Plover (Charadrius montanus) at agricultural and reference sites in North America. We found plasma AChE and $\mathrm{BChE}$ activities to be higher in North America than in South America for the White-rumped Sandpiper and Pectoral Sandpiper, respectively.

Elevated levels of BChE activity in Buff-breasted Sandpipers sampled at reference sites in North America and hemispheric variation in ChE of White-rumped and Pectoral Sandpipers might be due to four nonexclusive factors. First, changes in diet during migration between hemispheres can affect ChE activity (Van Lith et al. 1991, Goldstein et al. 1999b). Second, the amount of subcutaneous fat may partially explain variation in plasma $\mathrm{ChE}$ activity. A significant positive correlation between body fat and serum BChE activity has been reported in human patients (Randell 2005), and migratory shorebirds' fat reserves vary through their long-distance movements (Harrington et al. 1991). Moreover, our sampling of Buff-breasted Sandpipers in North America was temporally separated; we sampled at reference sites during northbound migration but at agricultural sites during southbound migration; fat reserves varied accordingly. Third, exposure to other contaminants not measured in this study could have affected plasma ChE activity. Dieter (1974) found that chronic dietary exposure of quail to low dose of DDE (a metabolite of the organochlorine DDT), Aroclor 1254 (a polychlorinated biphenyl), and mercuric chloride affected plasma TChE activity. Last, it is possible that birds were exposed to sublethal levels before we captured them. In this case, with sufficient time since exposure, $\mathrm{BChE}$ activity could have been elevated above reference-site levels in response to enzyme regeneration after such exposure (Soler-Rodriguez et al. 1998). Depending on the chemical compound, dosage, and time since exposure, plasma ChE activity may be at or above pre-exposure levels (Ludke et al. 1975, Fleming and Bradbury 1981, Fossi et al. 1992, SolerRodriguez et al. 1998). In laboratory work with quail, SolerRodriguez et al. (1998) documented elevated plasma TChE activity of $150 \%$ on day 4 that decreased to $100 \%$ on day 11 after exposure to the organophosphorus pesticide chlorpyrifos.

We used a meta-analysis to quantify the magnitude of variation in enzyme activity, finding effect sizes on $\mathrm{AChE}$ activity were negative in two of three species in each hemisphere. These effects ranged from small $(-0.10)$ to large $(-0.96)$. Conversely, in five of six comparisons the effect of treatment site on plasma $\mathrm{BChE}$ activity was positive. Although both cumulative effect sizes were nonsignificant, the upper confidence interval for the overall effect on $\mathrm{AChE}$ was only slightly greater than zero. The magnitude of the negative effect size on AChE activity of Buff-breasted Sandpipers, coupled with depressed levels of ChE activity seen in other poisoned species, leads us to conclude that Buff-breasted Sandpipers were exposed to ChE-inhibiting pesticides on the nonbreeding grounds. 
In cases like the Buff-breasted Sandpiper, where plasma ChE activity is lower at an agricultural site where use of pesticides was recommended, reactivation of plasma ChEs in vitro can provide useful evidence for exposure to $\mathrm{ChE}$ inhibitors. We were unable to successfully reactivate plasma ChEs by either the $\mathrm{OP}$ or $\mathrm{CB}$ methods. Null results from reactivation assays can be inconclusive, however, because some chemicals (i.e., dimethyl OPs) form a stable OP-enzyme complex through dealkylation and resist chemical reactivation (Wilson et al. 1992), as was the case with Swainson's Hawks (Buteo swainsoni) killed and incapacitated by the dimethyl OP monocrotophos (Goldstein et al. 1999b).

Extraction of chemical residues washed from feet can also provide forensic evidence of exposure to ChE inhibitors. Our analysis of foot washings yielded no evidence of recent dermal exposure to OPs or CBs. Rainwater et al. (1995) also found no chemical residues on the feet of birds whose plasma $\mathrm{ChE}$ activity indicated recent exposure to an anti-ChE, indicating that the birds may have been exposed at site away from where they were sampled. We attempted to sample shorebirds at sites where OPs and CBs were used for pest control but do not know the actual spatial and temporal patterns of insecticide use.

\section{BODY MASS}

One effect of ChE inhibition is reduced foraging ability and anorexia resulting in decreased body mass (Grue 1982, Grue et al. 1997). We tested for an effect of exposure to OPs and CBs by using body mass as an indicator of fitness and made comparisons by site and hemisphere. The birds' body mass varied by habitat, but our results indicated that shorebirds were able to maintain body mass at agricultural sites and even have higher mass there. Higher body masses might reflect better foraging conditions in agricultural areas that allow birds to compensate for any potential loss in foraging ability. Specifically, we were unable to detect an effect of exposure to $\mathrm{ChE}$ inhibitors on body mass in the Buff-breasted Sandpiper. In a laboratory study, Grue (1982) detected decreases in body mass in birds given doses of anti-ChEs sufficient to inhibit $59-67 \%$ of brain ChE activity, decreases that corresponded to mass loss of $5-9 \%$ in survivors. At lower doses and under chronic exposure, decreases in mass may be difficult to detect because of the considerable seasonal variation in body mass through the annual cycle. For example, heavier body masses of birds sampled in North America could have been due to these individuals' storing fat for migration. Shorebirds maintain and use large fat stores during migration, while they are comparatively lean while stationary on the nonbreeding grounds (Harrington et al. 1991).

\section{PLASMA AND BRAIN CHE ACTIVITY}

TChE activity (24.3 units $\mathrm{g}^{-1}$ brain $\pm 3.1, n=6$ ) in Buffbreasted Sandpiper brains was similar to values published for other shorebirds. Using similar methods for ChE analysis, Mitchell and White (1982) reported mean TChE activity of $22.8 \pm 5.6$ units $\mathrm{g}^{-1}$ brain $(n=60)$ in Western Sandpipers, $16.2 \pm 3.4$ units $\mathrm{g}^{-1}$ brain $(n=55)$ in Long-billed Dowitchers (Limnodromus scolopaceus), and $19.4 \pm 4.5$ units $\mathrm{g}^{-1}$ brain $(n=30)$ in American Avocets (Recurvirostra americana) sampled at Laguna Madre, Texas, during the nonbreeding season. Custer and Mitchell (1991) reported values between 11.1 and 17.8 units $\mathrm{g}^{-1}$ brain $(14.7 \pm 1.8, n=55)$ for Willets (Tringa semipalmata) sampled from the same area. The similarity of AChE activity of Buff-breasted Sandpiper brain to that of other shorebirds does not exclude exposure to OP and $\mathrm{CB}$ pesticides. The brain contains more $\mathrm{AChE}$ than $\mathrm{BChE}$, and larger doses of anti-ChEs are typically required to produce a detectable decrease in AChE in the brain than to produce one in plasma (Soler-Rodreiguez 1998). Samples of Buff-breasted Sandpiper brain were collected from turf-grass fields in Kansas where exposure to low doses of anti-ChE compounds was possible.

\section{SUMMARY AND RECOMMENDATIONS}

Our study is one of the first to evaluate exposure to ChEinhibiting pesticides in migratory shorebirds. Overall, most species of shorebirds showed little evidence of acute exposure. However, our results suggest that Buff-breasted Sandpipers were exposed to ChE-inhibiting pesticides in South America, and agricultural sites could have negative effects on plasma ChE activity in other shorebirds. Samples of Buff-breasted Sandpipers with depressed $\mathrm{ChE}$ levels originated from one site in Argentina where we captured no other species of shorebirds in large numbers. Depression of plasma ChE activity in Buff-breasted Sandpipers captured at agricultural sites in South America indicates a need for additional sampling at other sites where birds may be exposed. Future studies should include analyses of residues in prey collected in the field and assessments of exposure tied to applications of known antiChE insecticides (Hooper et al. 1989, Wilson et al. 1991). Furthermore, tracking individuals with radio-telemetry would clairify their habitat use and potential exposure away from sites of capture. We suggest continued cooperation and collaboration with partners in Argentina to continue assessments of habitat use, resulting pesticide exposure, and response in Buff-breasted Sandpipers on the nonbreeding grounds. Further monitoring could provide more robust sample sizes for additional species for which we provide baseline estimates of $\mathrm{ChE}$ activity and which could be used to evaluate exposure to other contaminants.

The expansion of agriculture into native habitats will continue to pose a conservation challenge to migratory birds. If recent trends of agricultural development continue, 8 million $\mathrm{km}^{2}$ of native habitat will be converted to crop and pastureland, worldwide, by 2050 (Tilman et al. 2001). Much of the expansion of agriculture into native habitats is projected to 
be in Latin America (Alexandratos 1999). Increases in pesticide use will likely follow. Development of new pesticides less toxic to nontarget species and recommendations for the timing of pesticide applications to provide maximum benefit to farmers while minimizing threats to migratory birds are also needed. Last, studies using stable isotopes and radio-telemetry are needed to clarify shorebirds' habitat use during migration and at nonbreeding sites (Fry et al. 1998, Farmer et al. 2004). Knowledge of use of specific agricultural habitat would facilitate assessment of exposure and characterization of specific chemical hazards, improving the cause-effect linkage needed to explain $\mathrm{ChE}$ inhibition in migratory shorebirds.

\section{ACKNOWLEDGMENTS}

In North America, we thank the owners and staff of Anahuac National Wildlife Refuge, turf-grass farms near Crosby, Texas, and Colwich and Lawrence, Kansas, Houston Audubon Bolivar Flats Shorebird Sanctuary, and Quivira National Wildlife Refuge. Stephanie Jones, Suzanne Fellows, Sherry Fleming, Stephanie Schmidt, Mark Robbins, Joel Jorgensen, John McCarty, and LaReesa Wolfenbarger provided logistical support, and Angela Matz contributed to the project development. In South America, access to field sites was provided by the staff of Guyra Paraguay, Instituto Nacional de Tecnología Agropecuaria de Argentina, Reserva Provincial Laguna Mar Chiquita y Bañados Rio Dulce, Inversul S.A., farmers in Departamento Treinta y Tres, Uruguay, and Guardaparques del Uruguay. Robert Owens, Hector Caimarys, the staff of Dirección Nacional de Recursos Acuáticos, Uruguay, and Freddie provided logistical support. In North America, field assistance was provided by Ashley Casey, Tara Conkling, Samantha Franks, Kyle Gerstner, Kate Goodenough, Karl Kosciuch, and the staff of the U.S. Department of Agriculture Wildlife Services Office in Manhattan, Kansas. In South America, staff from the Instituto Nacional de Tecnología Agropecuaria (INTA), Laura Addy, Natalia Bossel, Noelia Calamari, Julieta Decarre, Andrea Goijman, Benito Jaubert, Laura Solari, and Romina Suarez aided with field sampling, as well as Peter Doherty, Ben Haase, Leandro Macchi, and J. Neilson Merriwether. This work would not have been possible without collaboration with Julian Torres-Dowdall and Matilde Alfaro. Funding for field work and lab analyses was provided by grants from the Neotropical Migratory Bird Conservation Act and the Migratory Bird Management programs of the U.S. Fish and Wildlife Service. Additional support was provided by the Division of Biology at Kansas State University, the Institute for Environmental and Human Health at Texas Tech University, and the Department of Chemistry at Southern Illinois University, Edwardsville.

\section{LITERATURE CITED}

AleXAndratos, N. 1999. World food and agriculture: outlook for the medium and longer term. Proceedings of the National Academy of Sciences of the USA 96:5908-5914.

BAirlein, F. 1995. Manual of field methods: European-African songbird migration network. European Science Foundation, Wilhelmshaven, Germany.

Basili, G. D., And S. A. Temple. 1995. A perilous migration. Natural History 9:40-47.

Blanco, D. E., B. López-Lanús, R. A. Dias, A. Azpiroz, and F. RiLla. 2006. Use of rice fields by migratory shorebirds in southern South America: implications for conservation and management. Wetlands International, Buenos Aires, Argentina.
Brasel, J. M., A. C. Collier, And C. A. Pristos. 2005. Differential toxic effects of carbofuran and diazinon on time of flight in pigeons (Columba livia): potential for pesticide effects in migration. Toxicology and Applied Pharmacology 219:241-246.

Burger, J., S. Seyboldt, N. Morganstein, and K. Clark. 1993. Heavy metals and selenium in feathers of three shorebird species from Delaware Bay. Environmental Monitoring and Assessment 28:189-198.

COHEN, J. 1988. Statistical power analysis for the behavioral sciences, 2nd ed. Lawrence Earlbaum Associates, Hillsdale, NJ.

Custer, T. W., And C. A. Mitchell. 1991. Contaminant exposure of Willets feeding in agricultural drainages of the lower Rio Grande valley of south Texas. Environmental Monitoring and Assessment 16:189-200

Dieter, M. P. 1974. Plasma enzyme activities in Coturnix quail fed graded doses of DDE, polychlorinated biphenyl, malathion and mercuric chloride. Toxicology and Applied Pharmacology 27:86-98.

Ellman, G. L., K. D. Courtney, V. Andres, JR., And R. M. FEATHERSTONE. 1961. A new and rapid colorimetric determination of acetylcholinesterase activity. Biochemical Pharmacology 7:88-95.

Fair, J. M., P. L. Kennedy, And L. C. McEwen. 1995. Effects of carbaryl grasshopper control on nesting Killdeer in North Dakota. Environmental Toxicology and Chemistry 14:881-890.

Fagerness, M. J., N. Tisserat, B. BaUernfeind, AND J. D. Fry. 2001. Turfgrass pesticide selection guide for professional applicators 2001. Kansas State University Agricultural Experiment Station and Cooperative Extension Service, Manhattan, KS.

Farmer, A., M. Abril, M. Fernandez, J. Torres, C. Kester, And C. BERN. 2004. Using stable isotopes to associate migratory shorebirds with their wintering locations in Argentina. Ornitología Neotropical 15:1-8.

Fleming, W. J., AND S. P. BradBury. 1981. Recovery of cholinesterase activity in Mallard ducklings administered organophosphorus pesticides. Journal of Toxicology and Environmental Health 8:885-897.

Flickinger, E. L., K. A. King, W. F. Stout, And M. M. Mohn. 1980 Wildlife hazards from Furadan $3 \mathrm{G}$ applications to rice in Texas. Journal of Wildlife Management 44:190-197.

Flickinger, E. L., C. A. Mitchell, D. H. White, and E. J. Kolbe. 1986. Bird poisoning from misuse of the carbamate furadan in a Texas rice field. Wildlife Society Bulletin 14:59-62.

Fossi, C. M., C. Leonzio, A. Massi, L. LARI, And S. CAsini. 1992. Serum esterase inhibition from birds: a nondestructive biomarker to assess organophosphorus and carbamate contamination. Archives of Environmental Contamination and Toxicology 23:99-104

Fry, D. M., B. W. Willon, N. D. Ottum, J. T. Yamamoto, R. W. Stein, J. N. Seiber, M. M. McChesney, And E. Richardson. 1998. Radiotelemetry and GIS computer modeling as tools for analysis of exposure to organophosphate pesticides in Red-tailed Hawks, p. 67-83. In L. Brewer and K. Fagerstone [EDS.], Radiotelemetry applications for wildlife toxicology studies. Society for Environmental Toxicology and Chemistry, Pensacola, FL.

GARD, N. W., AND M. J. HoOPER. 1993. Age-dependent changes in plasma and brain cholinesterase activities of Eastern Bluebirds and European Starlings. Journal of Wildlife Diseases 29:1-7.

Gaunt, A. S., L. W. Oring, K. P. Able, D. W. Anderson, L. F. Baptista, J. C. BARlow, AND J. C. Wingfield. 1999. Guidelines to the use of wild birds in research. Ornithological Council, Washington, D.C.

Goldstein, M. I., T. E. Lacher, JR., B. WoOdbridge, M. J. Bechard, S. B. Canavelli, M. E. Zaccagnini, G. P. Cobb, E. J. Scollon, R. Tribolet, ANd M. J. HoOper. 1999a. Monocrotophos-induced 
mass mortality of Swainson's Hawks in Argentina, 1995-96. Ecotoxicology 8:201-214.

Goldstein, M. I., T. E. Lacher, JR., M. E. Zaccagnini, M. L. PARKER, AND M. J. HoOPER. 1999b. Monitoring and assessment of Swainson's Hawks in Argentina following restrictions on monocrotophos use, 1996-97. Ecotoxicology 8:215-224.

Grue, C. E. 1982. Response of Common Grackles to dietary concentrations of four organophosphate pesticides. Archives of Environmental Contamination and Toxicology 11:617-626.

Grue, C. E., P. L. GiberT, AND M. E. SEeley. 1997. Neurophysiological and behavioral changes in non-target wildlife exposed to organophosphate and carbamate pesticides: thermoregulation, food consumption, and reproduction. American Zoologist 37:369-388.

GuRevitch, J., AND L. V. Hedges. 1993. Meta-analysis: combining the results of independent experiments, p. 378-398. In S. M. Scheiner and J. Gurevitch [EDS.], Design and analysis of ecological experiments. Chapman and Hall, New York.

Harrington, B. A., F. J. LeeuwenberG, S. L. Resende, R. McNeil, B. T. Thomas, J. S. Grear, and E. F. Martinez. 1991. Migration and mass change of White-rumped Sandpipers in North and South America. Wilson Bulletin 103:621-636.

HILL, E. F. 1988. Brain cholinesterase activity for apparently normal wild birds. Journal of Wildlife Diseases 24:51-61.

Hooper, M. J., P. J. Detrich, C. P. Weisskopf, AND B. W. Wilson. 1989. Organophosphorus insecticide exposure in hawks inhabiting orchards during winter dormant-spraying. Bulletin of Environmental Contamination and Toxicology 42:651-659.

Hooper, M. J., P. Mineau, M. E. Zaccagnini, AND B. Woodbridge. 2003. Pesticides and international migratory bird conservation, p. 737-754. In D. J. Hoffman, B. A. Rattner, G. A. Burton, and J Cairns, Jr. [EDS.], Handbook of Ecotoxicology. Lewis Publishers, Boca Raton, FL.

Houston, C. S., And D. E. Bowen. 2001. Upland Sandpiper (Bartramia longicauda), no. 580. In A. Poole and F. Gill [EDS.], The birds of North America. Birds of North America, Inc., Philadelphia.

Hui, C. A., J. Y. TAKEKaWA, AND S. E. Warnock. 2001. Contaminant profiles of two species of shorebirds foraging together at two neighboring sites in South San Francisco Bay, California. Environmental Monitoring and Assessment 71:107-121.

HunT, K. A., AND M. J. HoOPER. 1993. Development and optimization of reactivation techniques for carbamate-inhibited brain and plasma cholinesterases in birds and mammals. Analytical Biochemistry 212:335-343.

Iko, W. M., A. S. ArchuletA, AND F. L. KNopf. 2003. Plasma cholinesterase levels of Mountain Plovers (Charadrius montanus) wintering in central California, USA. Environmental Toxicology and Chemistry 22:119-125.

Isacch, J. P., C. A. Darrieu, and M. M. Martínez. 2005. Food abundance and dietary relationships among migratory shorebirds using grasslands during the non-breeding season. Waterbirds 28:238-245

ISACCH, J. P., AND M. M. MARTíNEZ. 2003. Habitat use by non-breeding shorebirds in flooding pampas grasslands of Argentina. Waterbirds 26:494-500.

LEOPOLD, V. A. 1996. Esterase protection against diazinon toxicity in European Starlings. M.Sc. thesis, Clemson University, Clemson, SC.

LiTTRELL, E. E. 1998. Waterfowl mortality in rice fields treated with the carbamate, carbofuran. California Fish and Game 74:226-231.

LudKe, J. L., E. F. Hill, AND M. P. Dieter. 1975. Cholinesterase (ChE) response and related mortality among birds fed ChE inhibitors. Archives of Environmental Contamination and Toxicology $3: 1-21$.
Maul, J. D., AND J. L. FARRIS. 2005. Monitoring exposure of Northern Cardinals, Cardinalis cardinalis, to cholinesterase-inhibiting pesticides: enzyme activity, reactivations, and indicators of environmental stress. Environmental Toxicology and Chemistry 24:1721-1730.

McFarland, C. N., L. I. Bendell-Young, C. Guglielmo, and T. D. WiLLIAMS. 2002. Kidney, liver and bone cadmium content in the Western Sandpiper in relation to migration. Journal of Environmental Monitoring 4:791-795.

Mitchell, C. A., AND D. H. White. 1982. Seasonal brain acetylcholinesterase activity in three species of shorebirds overwintering in Texas. Bulletin of Environmental Contamination and Toxicology 29:360-365.

Myers, J. P., AND L. P. Myers. 1979. Shorebirds of coastal Buenos Aires Province, Argentina. Ibis 121:186-200.

NAGOSHI, R. N., AND R. L. MeAGHER. 2004. Seasonal distribution of fall armyworm (Lepidoptera: Noctuidae) host strains in agricultural and turf grass habitats. Environmental Entomology 33:881-889.

National Agricultural Statistics Service [online]. 2008. Agricultural chemical use database. $<$ http//www.pestmanagement. info/nass/app_usage.cfm> (9 January 2008).

Page, G. W., AND R. E. Gill, JR. 1994. Shorebirds in western North America: late 1800 's to late 1900's. Studies in Avian Biology 15:147-160.

PARKeR, M. L., AND M. I. GoldsteIn. 2000. Differential toxicities of organophosphate and carbamate insecticides in the nestling European Starling (Sturnus vulgaris). Archives of Environmental Contamination and Toxicology 39:233-242.

Prater, A. J., J. H. Marchant, ANd J. Vuioren. 1977. Guide to the identification and ageing of holarctic waders. Maud and Irvine Ltd., Tring, UK.

Rainwater, T. R., V. A. Leopold, M. J. Hooper, R. J. Kendall. 1995. Avian exposure to organophosphorus and carbamate pesticides on a coastal South Carolina golf course. Environmental Toxicology and Chemistry 14:2155-2161.

Randell, E. W., M. S. Mathews, H. Zhang, J. S. Seraj, and G. Sun 2005. Relationship between serum butyrylcholinesterase and the metabolic syndrome. Clinical Biochemistry 38:799-805.

RoBBins, M. B. 2007. Buff-breasted Sandpiper (Tryngites subruficollis) fall migration at sod farms in Kansas. Kansas Ornithological Society Bulletin 58:25-28.

Roy, C., G. Grolleau, S. Chamoulaud, and J.-L. Rivière. 2005. Plasma B-esterase activities in European raptors. Journal of Wildlife Diseases 41:184-208.

Senner, S. E., AND M. A. Howe. 1984. Conservation of nearctic shorebirds, p. 379-421. In J. Burger and B. L. Olla [EDS.], Behavior of marine animals: shorebirds, vol. 5. Plenum, New York.

SKagen, S. K., S. BROwn, AND R. JoHnson. 2005. Implications of different shorebird migration strategies for habitat conservation. USDA Forest Service General Technical Report PSWGTR-191.

SkAgEN, S. K., AND F. L. KNopf. 1993. Toward conservation of midcontinental shorebird migrations. Conservation Biology 7:533-541.

Skagen, S. K., P. B. Sharpe, R. G. Waltermire, and M. B. Dillon. 1999. Biogeographical profiles of shorebird migration in midcontinental North America. Biological Science Report USGS/BRD/ BSR - 2000-0003. U.S. Government Printing Office, Denver, CO.

Soler-Rodriguez, F., M. P. Miguez-Santiyan, A. Reja-Sanchez, V. Roncero-Cordero, AND J. P. Garcia-CAMBERO. 1998. Recovery of brain acetylcholinesterase and plasma cholinesterase activities in quail (Coturnix coturnix) after chlorpyrifos administration and effect of pralidoxime treatment. Environmental Toxicology and Chemistry 17:1835-1839. 
Soriano, A., R. J. C. León, O. E. Sala, R. S. Lavado, V. A. Deregibus, M. A. Cauhépé, C. A. Scaglia, C. A. VelázQuez, and J. H LemCoff. 1992. Río de la Plata grasslands, p. 367-407. In R. T. Coupland [ED.], Natural grasslands. Elsevier, Amsterdam.

Strum, K. M., M. Alfaro, B. Haase, M. J. Hooper, K. A. Johnson, R. B. Lanctot, A. J. Lesterhuis, L. López, A. C. Matz, C. Morales, B. Paulson, B. K. Sandercock, J. Torres-Dowdall, AND M. E. ZACCAGNINI. 2008. Plasma cholinesterases for monitoring pesticide exposure in nearctic-teotropical migratory shorebirds. Ornitología Neotropical 19 Suppl.:641-651.

Thompson, H. M. 1991. Serum "B" esterases as indicators of exposure to pesticides, p. 109-125. In P. Mineau [ED.], Cholinesteraseinhibiting insecticides. Elsevier, Amsterdam.

Tilman, D., J. Fargione, B. WolfF, C. D’Antonio, A. Dobson, R. Howarth, D. Schindler, W. H. Schlesinger, D. Simberloff, AND D. SWACKHAMER. 2001. Forecasting agriculturally driven global environmental change. Science 292:281-284.

Twedt, D. J., C. O. Nelms, V. E. Rettig, and S. R. Aycock. 1998 Shorebird use of managed wetlands in the Mississippi Alluvial Valley. American Midland Naturalist 140:140-152.

United States Environmental Protection Agency. [online]. 2006. Endangered species protection program. $<$ http://www.epa. gov/espp/kansas/stafford.htm> (28 April 2008).
Van Lith, H. A., L. F. M. Van Zutphen, and A. C. Beynen. 1991 Butyrylcholinesterase activity in plasma of rats and rabbits fed high-fat diets. Comparative Biochemistry and Physiology 98A: 339-342.

Vyas, N. B., W. J. Kuenzel, E. F. Hill, and J. R. Sauer. 1995. Acephate affects migratory orientation of the White-throated Sparrow (Zonotrichia albicollis). Environmental Toxicology and Chemistry 14:1961-1965.

WAY, M. O., AND J. CockRell. 2007. 2007 Texas rice production guidelines. Texas A\&M University, Beaumont, TX.

Wilson, B. W., M. J. Hooper, M. E. HANSEN, AND P. S. Nieberg 1992. Reactivation of organophosphorus inhibited AChE with oximes, p. 107-137. In J. E. Chambers and P. E. Levi [EDS.], Organophosphates: chemistry, fate, and effects, Academic Press, Orlando, FL.

Wilson, B. W., M. J. Hooper, E. E. Littrell, P. J. Detrich, M. E. Hansen, C. P. Weisskopf, And J. N. Seiber. 1991. Orchard dormant sprays and exposure of Red-tailed Hawks to organophosphates. Bulletin of Environmental Contamination and Toxicology 47:717-724.

ZÖCKLER, C., S. Delany, AND W. HagemeIJer. 2003. Wader populations are declining - how will we elucidate the reasons? Wader Study Group Bulletin 100:202-211. 